\title{
THE CONDITION OF COMPANIES AND THEIR GROWTH BASED ON THE EXAMPLE OF COMPANIES INCLUDED IN WIG AND DAX INDICES
}

\section{Monika Bolek* , Agata Gniadkowska-Szymańska**}

\begin{abstract}
The purpose of the article/hypothesis: The paper discusses the problem of condition of companies together with their growth measured by earnings per share, sales, assets and equity. The condition of a company in a capital market is considered good when the goal of the business is achieved, namely the increase of value that occurs with the increase of earnings per share. We assume that the condition of companies measured by Altman's Z-score Model scores is related to their growth, and ratios applied in this model influence the growth of companies measured by EPS, sales, assets and equity. The research is conducted in two groups of companies, one representing WIG listed entities and the other one comprising DAX listed companies.

Methodology: The growth of earnings per share is considered as a measure of companies' value creation. The growth of EPS should be related to the growth of sales, assets and equity according to the growth theory. To analyze the influence of Altman's Z-score Model on the growth of EPS, sales, assets and equity, the Pearson and Spearman correlation is applied in the first place. Moreover, logit models are applied to analyze the influence of ratios composing the Altman's Z-score Model on the growth of EPS, sales, assets and equity.

Results of the research: Discriminant models can be applied for the assessment of the economic condition of companies but the interpretation of the results should take into account the fact that risky strategies identified by Altman's Z-score Model as dangerous are related to the higher growth of earnings per share, therefore, there should be a negative relationship between Altman's Z-score Model scores and EPS growth and it was confirmed in this study.
\end{abstract}

Keywords: company growth, economic condition, Altman's Z-score Model.

JEL Class: G30, G32, G33, M2.

\footnotetext{
* Associate professor, Ph.D. Faculty of Economics and Sociology, University of Lodz; https://orcid.org/0000-0001-9376-1105.

${ }^{* *}$ Ph.D., Faculty of Economics and Sociology, University of Lodz; https://orcid.org/0000-0002-7321-3360.
} 


\section{INTRODUCTION}

The strategic goal of a company is related to its value maximization together with the growth of owners' benefits. According to Danbolt, Hirst and Jones (2011: 1-25) when earnings per share grows, then the value of the company grows as well. The condition of a company in a capital market is considered to be good when the goal of the business is achieved along with the increase of value that occurs along with the increase of earnings per share.

Altman's or similar, so called bankruptcy models can be also applied in the field of financial condition assessment (Altman and Hotchkiss, 2006: 248). We assume that the condition of companies measured by Altman's Z-score Model scores is related to their value growth in the opposite direction, and levels of ratios applied in this model are related to the growth of companies represented by EPS, sales, assets and equity. The research is done in two groups of companies, one representing WIG listed entities and the other one comprising DAX listed companies.

The research is composed of several parts. First of all, the statistical analysis of samples is presented. Secondly, the correlation analysis is provided to test the results on the relation between growth od EPS, sales, assets and equity and scores in Altman's Model. In the third step the logit models are tested with the growth factors as endogenous measures and ratios that compose Altman's Z-score Model as exogenous ones. Finally, the correlation between growth measures in both groups of companies is analyzed in order to prove the consistency of their development. The results can help to understand the relationship between growth measures and Altman's Z-score Model with its components to optimize the management decisions in companies in capital market.

The paper is composed of the following sections: a literature review, methods and data, results, discussion and conclusions.

\section{LITERATURE REVIEW}

A more advanced method of assessing the company financial situation than the analysis of financial ratios is provided by discriminatory models, also known as bankruptcy early warning systems (Siekelova et al., 2019: 89-97). The assessment resulting from these models is aimed at analyzing the risk of bankruptcy of the examined companies but also its financial condition with the method of bonds rating (Altman and Hotchkiss, 2006: 248). In the literature there are a lot of proposals to use early warning systems for company condition assessment (Piotroski, 2000: 1-41; Grice and Ingram, 2001: 53-61; Griffin and Lemmon, 
2002: 2317-2336; Franzen et al., 2007: 2931-2967; Xu and Zhang, 2009: 534558). Moreover, Altman's Z-score Model can be used by banks for classifying their clients (El Khoury and Al Beaïno, 2014:11-18). The enormous application of bankruptcy models, in practice, results from their simplicity and effectiveness for assessing changes in the financial condition of companies (Vochozka et al., 2020: 7529).

Discriminatory models enable to assess the economic condition of business entities, but first of all, they were created for detecting bankruptcy (see: Altman et al., 2014: 220-236; Aktas et al., 2012: 1402-1413; Lyandres and Zhdanov, 2013: 439-476). The possibility of predicting bankruptcy has always been an area of interest for many scientists. That is why many attempts were made to construct tools that would precisely define whether the company was at risk of bankruptcy or not (Kanapickiene and Spicas, 2019: 67; Bărbuță-Mișu and Madaleno, 2020: 58). The general need to build this type of tools appeared for the first time during the Great Depression. The first discriminant model was developed in the United States of America in 1932 by Fitzpatrick (1932), who proposed a one-dimensional model. Its creation was based on a large number of corporate bankruptcies that hit America during the Great Economic Crisis. The analysis carried out by Fitzpatrick concerned 38 companies - half of them were in a good financial condition, the rest went bankrupt. However, the most famous one-dimensional early warning system was developed by Beaver (1966), who examined 79 solvent and insolvent American companies. These companies, contrary to the previously described model, belonged to different industries, but were similar in terms of legal form and size (Zalewska, 2002).

Altman's Model can be considered a precursor between multidimensional discriminant analysis to forecast the risk of company bankruptcy. Altman constructed the Z-score model based on financial data of 66 American companies - out of which 33 failed and 33 continuously operated on the market (Altman, 1968: 589-609; Altman, 1983; Altman and Hotchkiss, 2006, Altman et.al., 2010: 220-236). The companies were selected in terms of the industry and the value of the balance sheets. The research initiated by Altman has been continued by numerous authors developing similar models for the economies of different countries and applying more and more innovative methods of multivariate data analysis (Waśniewski and Skoczylas, 1993; Kasiewicz, 1996; Hadasik, 1998; Kumar and Ravi, 2007; Merkevicius et al., 2006: 364-371; Kwak et al., 2005: 164-173). The methods of distinguishing companies with the score assessment appeared to be very useful for investors and managers in capital market.

The great advantage of using early warning systems is the trouble-free interpretation of the results. Quick and effective assessment of the condition of the company on the basis of economic and financial data is possible while basing on information from the balance sheet and the profit and loss account (see: Franc- 
-Dąbrowska and Zbrowska, 2008: 251; Holder-Webb and Wilkins, 2000: 209219; Chava and Jarrow, 2000: 537-569; Reisz and Perlich, 2007: 85-131).

The growth of the company is related to the measurable changes occurring in the economic entity, which may be reflected by the increase in sales, assets, equity and earnings per share (Bankole and Ukolobi, 2020: 2222-1697). Appropriate and effective transformations in the company allow to develop a competitive advantage (Czerwińska et al., 2013: 79-80). The growth, depending on the stage of development, may be sustainable or dynamic but it always indicates a good economic condition when a company invests in profitable projects (Witkowska and Kuźnik, 2019: 85-96). The growth of company referring to its value is measured by the EPS growth (Danbolt at al., 2011: 1-25]. Other growth measures as sales, assets and equity should change in line with EPS growth if the growth is coherent.

EPS growth influencing the growth of company value was analyzed by Ahmed and Nanda (2001: 47-59), Ohlson, and Juettner-Nauroth (2005: 349-365) and Ohlson (2017). Joining the issues of condition assessment and value creation of companies on capital market should influence the efficiency of financial management, especially when Altman's Model needs broader interpretation. Companies with a high scoring should generate low levels of EPS growth while companies with a low, but still acceptable scoring, should generate higher levels of EPS growth. We are expecting to prove this statement in further sections.

\section{METHODOLOGY AND DATA}

This paper examines companies from the Warsaw Stock Exchange (WSE) which were included in WIG index in the last quarter of 2017 and from the German market, which were included in DAX index in the last quarter of 2017. The source of data related to financial statements and market prices is based on the Bloomberg database ${ }^{1}$.

The survey was carried out on the data from the period between March 31, 2012 - December 31, 2017. The survey was conducted on quarterly rates calculated on the basis of prices from the last day of each quarter. The group of companies that meet the following conditions are selected for the survey if:

- they were listed on the WSE/ Börse Frankfurt throughout the entire period,

- they were included in the WIG/DAX Index.

\footnotetext{
${ }^{1}$ Prices of shares and ratios have been adjusted for any transactions that could artificially affect the rate of return, such as splits, subscription rights, dividends, share buybacks, etc., according to the methodology data provider.
} 
In this way, 152 companies meeting the above mentioned criteria are selected from WIG Index and only 17 companies meeting the above mentioned criteria are selected from DAX Index. A database contained the original:

- 3648 observations of company/ quarter for the main market of the WSE,

- 408 records of company/ quarter for the German market.

An average sum of assets in a group of companies included in WIG index was equal to $2461,81 \mathrm{~K}$ and in a group of companies included in DAX Index $187127,20 \mathrm{~K}$ Euro. The companies included in DAX Index were significantly larger compared to companies included in WIG Index.

Delmar (2006) and Weinzimmer et al. (1998) proposed a general indicator for measuring the growth.

$$
\mathrm{g}=\frac{\mathrm{R}_{\mathrm{t} 1}-\mathrm{R}_{\mathrm{t} 0}}{\mathrm{R}_{\mathrm{t} 0}}
$$

where:

$\mathrm{g}$ - total growth rate of a given factor,

$\mathrm{R}_{\mathrm{t} 0}$ - size at the beginning of the period,

$\mathrm{R}_{\mathrm{t} 1}$ - size at the end of the period.

The growth of sales, assets and equity were calculated using the formula (1) but the EPS growth, due to its possible negative levels, was calculated with total assets in denominator. The growth was calculated for 1 period ahead.

Altman's Z-score Model is composed of five selected indicators:

$\mathrm{A} W 1=$ working capital/ assets (WC/TA)

$\mathrm{A} W 2=$ cumulated retained earnings/ assets $(\mathrm{CRE} / \mathrm{TA})$

$\mathrm{A} W 3=$ operational profit/assets $(\mathrm{EBIT} / \mathrm{TA})$

$\mathrm{A} W 4=$ market value of equity/ book value of debt (MVE/BVD)

$\mathrm{A} W 5=$ sales /assets $(\mathrm{S} / \mathrm{TA})$

Market value of equity was calculated on the last day of each quarter.

After applying the discriminant analysis method, the following function was estimated:

$$
\text { ZScore }=1,2 W 1+1,4 W 2+3,3 W 3+0,6 W 4+1,0 W 5
$$

The classification criteria for companies are presented in Table 1 . 
First of all, Pearson and Spearman correlation was applied to recognize the linear and nonlinear relationship between Altman's Z-score Model scores and growth of companies represented by EPS, sales, assets and equity.

Table 1. Criteria for classification of companies in the Altman's system

\begin{tabular}{|c|c|c|}
\hline Economic condition & $\mathrm{Z}$ value & Rating \\
\hline \multirow{9}{*}{ Safe range } & 8,15 & AAA \\
\hline & 7,6 & AA+ \\
\hline & 7,3 & AA- \\
\hline & 7 & AA- \\
\hline & 6,85 & $\mathrm{~A}+$ \\
\hline & 6,65 & $\mathrm{~A}$ \\
\hline & 6,4 & $\mathrm{~A}-$ \\
\hline & 6,25 & $\mathrm{BBB}+$ \\
\hline & 5,85 & BBB \\
\hline \multirow{6}{*}{ Insecure range } & 5,65 & BBB- \\
\hline & 5,25 & $\mathrm{BB}+$ \\
\hline & 4,95 & BB \\
\hline & 4,75 & BB- \\
\hline & 4,5 & $\mathrm{~B}+$ \\
\hline & 4,15 & B \\
\hline \multirow{5}{*}{ Dangerous range } & 3,75 & $\mathrm{~B}-$ \\
\hline & 3,2 & $\mathrm{CCC}+$ \\
\hline & 2,5 & $\mathrm{CCC}$ \\
\hline & 1,75 & $\mathrm{CCC}_{-}$ \\
\hline & 0 & $\mathrm{D}$ \\
\hline
\end{tabular}

Source: In-Depth Data Corp on the basis of 750 companies with corporate debt ratings, Altman and Hotchkiss, 2006: 248. Corporate financial distress and bankruptcy (3d) Wiley, provided by stockwatch.pl

In the second step, the binary logit model parameters were estimated based on cross-sectional data. The model was specified as follows:

$$
y_{i}=\alpha_{0}+\alpha_{1} \cdot x_{1, i}+\alpha_{2} \cdot x_{2, i}+\cdots+\alpha_{k} \cdot x_{k, i}+\xi_{i}
$$

EPS, sales, assets and equity growth as endogenous variables were taken into consideration with exogenous variables represented by Altman's Z-score Model ratios.

In the binary logit model, a company performance represented by positive changes of growth measures gEPS $>0, \mathrm{gS}>0, \mathrm{gA}>0$ and $\mathrm{gE}>0$ was classified as a positive direction of change with variable equal to 1 , otherwise it is equal to 0 . 


$$
\ln \left(\frac{p_{i}}{1-p_{i}}\right)=\alpha_{0}+\alpha_{1} \cdot x_{1, i}+\alpha_{2} \cdot x_{2, i}+\cdots+\alpha_{k} \cdot x_{k, i}+\xi_{i}
$$

where: $p_{i}$ denotes probability that a given firm in a given period, which denotes record of a number $i$, has FP equal to $1 . x_{1}, x_{2}, \ldots, x_{k}$ are explanatory variables, $\alpha_{0}, \alpha_{1}, \ldots, \alpha_{k}$ are parameters , and $\xi_{i}$ is an error term.

$\mathrm{R}$-squared and prediction levels of logit models were found relatively low because the purpose of this model was not related to the explanation of the growth in itself, but they were built to identify the direction and significance of the influence of chosen variables on the growth measures.

\section{RESULTS}

In the first step the analysis of the statistics of variables is provided. The growth of earnings per share (gEPS), growth of sales $(\mathrm{gS})$, growth of assets $(\mathrm{gA})$ and growth of equity (gE) were analyzed in Table 2 and 3, respectively for WIG and DAX listed companies.

Table 2. Descriptive statistics of growth factors for the observations in a sample 1-3541 for WIG listed companies

\begin{tabular}{|c|c|c|c|c|c|}
\hline Variable & Mean & Median & S.D. & Min & Max \\
\hline $\mathrm{gEPS}$ & 0.00035 & 0.000 & 0.0229 & -0.613 & 0.275 \\
\hline $\mathrm{gS}$ & 0.0612 & 0.00737 & 0.502 & -0.856 & 18.00 \\
\hline $\mathrm{gA}$ & 0.0144 & 0.00495 & 0.0993 & -0.572 & 1.39 \\
\hline $\mathrm{gE}$ & 0.00631 & 0.00959 & 0.31 & -16.9 & 1.73 \\
\hline
\end{tabular}

Source: author's own study.

Table 3. Descriptive statistics of growth factors for the observations in a sample 1-409 for DAX listed companies

\begin{tabular}{|c|c|c|c|c|c|}
\hline Variable & Mean & Median & S.D. & Min & Max \\
\hline $\mathrm{gEPS}$ & 0.000 & 0.000 & 0.0001 & -0.001 & 0.0009 \\
\hline $\mathrm{gS}$ & 0.0036 & 0.0104 & 0.134 & -1.00 & 0.501 \\
\hline $\mathrm{gA}$ & 0.0059 & 0.0067 & 0.0869 & -1.00 & 0.311 \\
\hline $\mathrm{gE}$ & 0.0185 & 0.0164 & 0.152 & -0.763 & 1.82 \\
\hline
\end{tabular}

Source: author's own study. 
The growth was higher for EPS in the group of companies included in WIG Index. The growth of equity was higher in the group of companies included in DAX Index indicating higher investments in larger companies. Variability of growth factors was higher in the group of companies included in WIG Index.

Having Altman's Z-score Model taken into consideration, the descriptive statistics regarding the levels of ratios that compose the final score are presented in Table 4 and 5 for WIG and DAX listed companies respectively.

Table 4. Descriptive statistics of Altman Model for the observations in a sample 1-3541 for WIG listed companies

\begin{tabular}{|c|c|c|c|c|c|}
\hline Variable & Mean & Median & S.D. & Min & Max \\
\hline WC/TA & 0.0317 & 0.0000 & 0.466 & -0.0132 & 13.3 \\
\hline CRE/TA & 0.0000 & 0.0000 & 0.00348 & -0.0333 & 0.167 \\
\hline EBIT/TA & 0.0148 & 0.0134 & 0.0253 & -0.204 & 0.514 \\
\hline MVE/BVD & 1.82 & 1.20 & 2.90 & -0.447 & 64.1 \\
\hline S/TA & 0.321 & 0.271 & 0.221 & 0.00191 & 2.75 \\
\hline Suma A & 1.50 & 1.11 & 1.95 & 0.0826 & 39.0 \\
\hline
\end{tabular}

Source: author's own study.

Table 5. Descriptive statistics of Altman Model for the observations in a sample 1-409 for DAX listed companies

\begin{tabular}{|c|c|c|c|c|c|}
\hline Variable & Mean & Median & S.D. & Min & Max \\
\hline WC/TA & 0.0000 & 0.0000 & 0.0000 & 0.0000 & 0.0000 \\
\hline CRE/TA & 0.0000 & 0.0000 & 0.0000 & 0.0000 & 0.000212 \\
\hline EBIT/TA & 0.0177 & 0.0190 & 0.0167 & -0.130 & 0.0665 \\
\hline MVE/BVD & 0.634 & 0.579 & 0.410 & 0.0206 & 2.44 \\
\hline S/TA & 0.210 & 0.183 & 0.0781 & 0.0823 & 0.431 \\
\hline Suma A & 0.649 & 0.667 & 0.274 & -0.0505 & 1.73 \\
\hline
\end{tabular}

Source: author's own study.

The correlation between the growth measures and Altman's Z-score Model total scores is analyzed in the next step, and the result are presented in Table 6 and Table 7. First, the linear relationship between variables is taken into consideration and Pearson correlation is applied, and in the second step, the Spearman's rho is calculated to analyze a non-linear relationship between the variables. 
Table 6. Pearson Correlation between Altman's Z-score Model total scores and growth ratios

\begin{tabular}{|c|c|c|c|c|}
\hline & gEPS & gS & gA & gE \\
\hline \multicolumn{5}{|c|}{ WIG listed companies } \\
\hline $\begin{array}{c}\text { Altman } \\
\text { Pearson correlation }\end{array}$ & -0.0136 & 0.0250 & 0.0146 & -0.0192 \\
\hline t (3504) & -0.8079 & 1.4816 & 0.8681 & -1.1388 \\
\hline two-tailed p-value & 0.4192 & 0.3854 & 0.3854 & 0.2548 \\
\hline \multicolumn{7}{|c|}{ DAX listed companies } \\
\hline $\begin{array}{c}\text { Altman } \\
\text { Pearson correlation }\end{array}$ & -0.1315 & 0.0132 & $0.1728 *$ & -0.018 \\
\hline t (407) & -2.6772 & 0.2664 & 3.5397 & -0.3760 \\
\hline two-tailed p-value & 0.0077 & 0.7901 & 0.0004 & 0.7071 \\
\hline
\end{tabular}

* Results are statistically significant

Source: author's own elaboration.

Table 7. Spearman's rho coefficient for Altman total scores and growth ratios

\begin{tabular}{|c|c|c|c|c|}
\hline & gEPS & gS & gA & gE \\
\hline \multicolumn{1}{|c|}{ WIG listed companies } \\
\hline $\begin{array}{c}\text { Altman } \\
\text { Spearman rho correlation }\end{array}$ & $-0.079 *$ & $-0.0786 *$ & $0.0610 *$ & -0.0165 \\
\hline t (3504) & -4.7154 & -4.6720 & 3.6178 & -0.9794 \\
\hline two-tailed p-value & 0.0000 & 0.0000 & 0.0003 & 0.3274 \\
\hline \multicolumn{5}{|c|}{ DAX listed companies } \\
\hline Altman & -0.0549 & -0.0232 & $0.1278 *$ & $0.1208 *$ \\
\hline Spearman rho correlation & -1.1099 & -0.4691 & 2.6015 & 2.4554 \\
\hline two7) & 0.2677 & 0.6393 & 0.0096 & 0.0145 \\
\hline
\end{tabular}

* Results are statistically significant

Source: author's own elaboration.

The growth of EPS was correlated to the Altman's Z-score Model scores in a negative way in both groups of companies. The difference is that this relationship was linear in case of companies included in DAX Index, and non-linear in case of companies included in WIG Index. In case of growth of sales the only significant correlation was found in a group of companies included in WIG Index, and the sign was negative indicating the growth of sales when the condition of companies as measured by Altman's Z-score Model was worsening. This finding can indicate the distress situation when a company applies a more risky sales policy resulting in a higher growth (probably only in a short term). In case of growth of assets, the correlation was positive for both groups, but this relationship was non-linear in case of WIG listed companies. The growth of equity 
was correlated with Altman's Z-score Model scores in a positive way only in a group of companies included in DAX Index, and this correlation was not linear.

In the next step the analysis of ratios that compose the Altman's Z-score Model influencing the growth of companies are analyzed using the logit binary models with EPS, sales, assets and equity growth as discrete variables.

The growth of EPS for WIG and DAX listed companies determined by Altman's Z-score Model ratios are presented in Table 8 and 9.

Table 8. Binary logit model, no of observations 3541 for companies included in WIG.

Dependent variable: $\operatorname{logEPS}$ growth

\begin{tabular}{|c|c|c|c|c|c|}
\hline & Coefficient & Std. Error & $z$ & $p$-value & \\
\hline Const & 0.1397 & 0.0733 & 1.906 & 0.0567 & $*$ \\
\hline WC/TA & 0.0032 & 0.0793 & 0.04041 & 0.9678 & \\
\hline CRE/TA & 11.3052 & 12.1458 & 0.9308 & 0.3520 & \\
\hline EBIT/TA & -1.9728 & 1.3999 & -1.409 & 0.1588 & \\
\hline MVE/BVD & -0.0408 & 0.0157 & -2.597 & 0.0094 & $* * *$ \\
\hline S/TA & -0.2279 & 0.1647 & -1.383 & 0.1666 & \\
\hline Mean dependent var & 0.491298 & \multicolumn{2}{|l|}{ S.D. dependent var } & 0.499996 \\
\hline McFadden R-squared & 0.002722 & \multicolumn{5}{|l|}{ Adjusted R-squared } & 0.000252 \\
\hline
\end{tabular}

The parameter is statistically significant for any p-value less than 0.1 for increasing confidence $1 \%(* * *), 5 \%(* *)$ i $10 \%(*)$.

Source: author's own elaboration.

Table 9. Binary logit model, no of observations 409 for companies included in DAX.

Dependent variable: $\log$ EPS

\begin{tabular}{|c|c|c|c|c|c|}
\hline & Coefficient & Std. Error & $z$ & p-value & \\
\hline Const & -0.3836 & 0.3869 & -0.9916 & 0.3214 & \\
\hline WC/TA & -2745 & 7165 & -0.3832 & 0.7015 & \\
\hline CRE/TA & 17859.1 & 15307.1 & 1.167 & 0.2433 & \\
\hline EBIT/TA & -59.7233 & 11.7386 & -5.088 & $<0.0001$ & $* * *$ \\
\hline MVE/BVD & 1.21190 & 0.3928 & 3.085 & 0.0020 & $* * *$ \\
\hline S/TA & 3.1978 & 1.5093 & 2.119 & 0.0341 & $* *$ \\
\hline Mean dependent var & 0.4889 & \multicolumn{2}{|l|}{ S.D. dependent var } & 0.5004 \\
\hline McFadden R-squared & 0.0705 & \multicolumn{2}{|l|}{ Adjusted R-squared } & 0.0493 \\
\hline
\end{tabular}

The parameter is statistically significant for any p-value less than 0.1 for increasing confidence $1 \%(* * *), 5 \%(* *)$ i $10 \%(*)$.

Source: author's own study. 
In case of companies included in WIG Index only the market value of equity/book value of debt (MVE/BVD) influenced the growth of EPS in a negative way. In case of companies included in DAX Index, operational profit/assets (EBIT/TA) influenced the growth of EPS in a negative way and market value of equity/ book value of debt (MVE/BVD) and sales /assets (S/TA) in a positive way.

The growth of sales influenced by Altman's Z-score Model scores is presented in Table 10 and 11 for WIG and DAX listed companies respectively.

Table 10. Binary logit model, no of observations 3541 for companies included in WIG Index.

Dependent variable: $\log S$

\begin{tabular}{|c|c|c|c|c|c|}
\hline & Coefficient & Std. Error & $z$ & $p$-value & \\
\hline Const & 0.5105 & 0.07544 & 6.767 & $<0.0001$ & $* * *$ \\
\hline WC/TA & -0.054 & 0.0894 & -0.6034 & 0.5463 & \\
\hline CRE/TA & 1.5704 & 9.9168 & 0.1584 & 0.8742 & \\
\hline EBIT/TA & -14.2835 & 1.6815 & -8.495 & $<0.0001$ & $* * *$ \\
\hline MVE/BVD & -0.0304 & 0.0139 & -2.184 & 0.0290 & $* *$ \\
\hline S/TA & -0.5098 & 0.1729 & -2.948 & 0.0032 & $* * *$ \\
\hline Mean dependent var & 0.5196 & \multicolumn{5}{|l|}{ S.D. dependent var } & 0.4996 \\
\hline \multicolumn{2}{|l|}{ McFadden R-squared } & 0.0227 & Adjusted R-squared & 0.0202 \\
\hline
\end{tabular}

The parameter is statistically significant for any p-value less than 0.1 for increasing confidence $1 \%(* * *), 5 \%(* *)$ i $10 \%(*)$.

Source: author's own study.

Table 11. Binary logit model, no of observations 409 for companies included in DAX Index.

Dependent variable: $\log S$

\begin{tabular}{|c|c|c|c|c|c|}
\hline & Coefficient & Std. Error & $Z$ & p-value & \\
\hline Const & 0.4481 & 0.3757 & 1.193 & 0.2330 & \\
\hline WC/TA & 4095 & 7404 & 0.5532 & 0.5801 & \\
\hline CRE/TA & -1720.59 & 7807.45 & -0.2204 & 0.8256 & \\
\hline EBIT/TA & -28.3642 & 9.4328 & -3.007 & 0.0026 & $* * *$ \\
\hline MVE/BVD & 0.5836 & 0.3629 & 1.608 & 0.1078 & \\
\hline S/TA & -0.5006 & 1.42870 & -0.3504 & 0.7260 & \\
\hline Mean dependent var & 0.5525 & \multicolumn{5}{|l|}{ S.D. dependent var } & 0.4978 \\
\hline McFadden R-squared & 0.0300 & \multicolumn{5}{|l|}{ AdjustedR-squared } & 0.0087 \\
\hline
\end{tabular}

The parameter is statistically significant for any p-value less than 0.1 for increasing confidence $1 \%(* * *), 5 \%(* *)$ i $10 \%(*)$.

Source: author's own study. 
In case of companies included in WIG Index operational profit/assets (EBIT/TA), market value of equity/ book value of debt (MVE/BVD) and sales /assets (S/TA) influenced the growth of sales in a negative way, while in case of companies included in DAX Index, only operational profit/assets (EBIT/TA) influenced the growth of sales in a negative way.

The growth of assets influenced by Altman's Z-score Model scores is presented in Table 12 and 13 for companies included in WIG and DAX Indices respectively.

Table 12. Binary logit model, no of observations 3541 for companies included in WIG Index.

Dependent variable: $\log \mathrm{A}$

\begin{tabular}{|c|c|c|c|c|c|}
\hline & Coefficient & Std. Error & $Z$ & p-value & \\
\hline Const & 0.0898 & 0.0707 & 1.269 & 0.2044 & \\
\hline WC/TA & -0.0950 & 0.0809 & -1.173 & 0.2407 & \\
\hline CRE/TA & 2.1560 & 9.9353 & 0.2170 & 0.8282 & \\
\hline EBIT/TA & 4.7661 & 1.4592 & 3.266 & 0.0011 & $* * *$ \\
\hline MVE/BVD & 0.0019 & 0.0128 & 0.1520 & 0.8792 & \\
\hline S/TA & 0.0346 & 0.1638 & 0.2115 & 0.8325 & \\
\hline Mean dependent var & 0.5427 & S.D. dependent var & 0.4982 \\
\hline McFadden R-squared & 0.0028 & $\begin{array}{c}\text { Adjusted } \\
\text { R-squared }\end{array}$ & 0.0003 \\
\hline
\end{tabular}

The parameter is statistically significant for any p-value less than 0.1 for increasing confidence $1 \%(* * *), 5 \%(* *)$ i $10 \%(*)$.

Source: author's own study.

Table 13. Binary logit model, no of observations 409 for companies included in DAX Index.

Dependent variable: $\log \mathrm{A}$

\begin{tabular}{|c|c|c|c|c|c|c|}
\hline & \multicolumn{2}{|c|}{ Coefficient } & Std. Error & $Z$ & $\overline{p \text {-value }}$ & \\
\hline const & \multicolumn{2}{|c|}{-0.1220} & 0.3705 & -0.3293 & 0.7419 & \\
\hline WC/TA & \multicolumn{2}{|c|}{97130.6} & 71745 & 0.1354 & 0.8923 & \\
\hline CRE/TA & \multicolumn{2}{|c|}{3432.67} & 8054.74 & 0.4262 & 0.6700 & \\
\hline EBIT/TA & \multicolumn{2}{|c|}{-3.7281} & 7.108 & -0.5244 & 0.6000 & \\
\hline MVE/BVD & \multicolumn{2}{|c|}{0.6735} & 0.3491 & 1.929 & 0.0537 & * \\
\hline S/TA & \multicolumn{2}{|c|}{0.2442} & 1.3767 & 0.1774 & 0.8592 & \\
\hline \multicolumn{2}{|c|}{ Mean dependent var } & 0.5721 & & \multicolumn{2}{|c|}{ S.D. dependent var } & 0.4953 \\
\hline \multicolumn{2}{|c|}{ McFadden R-squared } & 0.0118 & & \multicolumn{2}{|c|}{ Adjusted R-squared } & -0.0096 \\
\hline
\end{tabular}

The parameter is statistically significant for any p-value less than 0.1 for increasing confidence $1 \%(* * *), 5 \%(* *)$ i $10 \%(*)$.

Source: author's own study. 
In case of companies included in WIG Index only operational profit/assets (EBIT/TA) influenced the growth of assets in a positive way, while in case of companies included in DAX Index, value of equity/ book value of debt (MVE/BVD) influenced it in the same direction.

The growth of equity influenced by Altman's Z-score Model ratios is presented in Table 14 and 15 for companies included in WIG and DAX Indices respectively .

Table 14. Binary logit model, no of observations 3541 for companies included in WIG Index.

Dependent variable: $\log \mathrm{E}$

\begin{tabular}{|c|c|c|c|c|c|}
\hline & Coefficient & Std. Error & $Z$ & $p$-value & \\
\hline Const & 0.2759 & 0.0758 & 3.638 & 0.0003 & $* * *$ \\
\hline WC/TA & -0.0386 & 0.0790 & -0.4891 & 0.6248 & \\
\hline CRE/TA & -15.0155 & 12.6961 & -1.183 & 0.2369 & \\
\hline EBIT/TA & 7.7448 & 1.5545 & 4.982 & $<0.0001$ & $* *$ \\
\hline MVE/BVD & -0.0314 & 0.01427 & -2.201 & 0.0277 & $*$ \\
\hline S/TA & 0.3730 & 0.1781 & 2.094 & 0.0363 & $* *$ \\
\hline Mean dependent var & 0.6095 & \multicolumn{2}{|c|}{ S.D. dependent var } & 0.4879 \\
\hline McFadden R-squared & 0.0099 & \multicolumn{2}{|c|}{ Adjusted R-squared } & \multicolumn{2}{|c|}{0.0073} \\
\hline
\end{tabular}

The parameter is statistically significant for any p-value less than 0.1 for increasing confidence $1 \%(* * *), 5 \%(* *)$ i $10 \%(*)$.

Source: author's own study.

Table 15. Binary logit model, no of observations 409 for companies included in DAX Index.

Dependent variable: $\log \mathrm{E}$

\begin{tabular}{|c|c|c|c|c|c|}
\hline & Coefficient & Std. Error & $Z$ & p-value & \\
\hline Const & 0.0424 & 0.3781 & 0.1121 & 0.9107 & \\
\hline WC/TA & 9794 & 9722 & 1.007 & 0.3137 & \\
\hline CRE/TA & -11612.6 & 12063.0 & -0.9627 & 0.3357 & \\
\hline EBIT/TA & 2.9713 & 7.2078 & 0.4122 & 0.6802 & \\
\hline MVE/BVD & 0.7690 & 0.3667 & 2.097 & 0.0360 & $* *$ \\
\hline S/TA & -0.2617 & 1.4022 & -0.1867 & 0.8519 & \\
\hline Mean dependent var & 0.6308 & S.D. dependent var & 0.4831 \\
\hline McFadden R-squared & 0.0307 & \multicolumn{2}{|c|}{$\begin{array}{c}\text { Adjusted } \\
\text { R-squared }\end{array}$} \\
\hline
\end{tabular}

The parameter is statistically significant for any p-value less than 0.1 for increasing confidence $1 \%(* * *), 5 \%(* *)$ i $10 \%(*)$.

Source: author's own elaboration. 
In case of companies included in WIG Index operational profit/assets (EBIT/TA) and sales /assets (S/TA) influenced the growth of equity in a positive way and market value of equity/ book value of debt (MVE/BVD) in a negative way and in case of companies included in DAX Index only the market value of equity/ book value of debt (MVE/BVD) influenced the growth of equity in a positive way.

The growth of EPS should be correlated with other indicators of growth, if companies develop in a coherent way. The Pearson and Spearman correlation measures between EPS growth and growth of sales, assets and equity are calculated for both group of companies and presented in Table 16 and 17.

Table 16. Pearson Correlation between growth ratios

\begin{tabular}{|c|c|c|c|}
\hline & $\mathrm{gS}$ & $\mathrm{gA}$ & $\mathrm{gE}$ \\
\hline \multicolumn{4}{|c|}{ Companies included in WIG Index } \\
\hline $\begin{array}{c}\text { gEPS } \\
\text { Pearson correlation }\end{array}$ & $0.1553 *$ & $0.1130^{*}$ & $0.1388 *$ \\
\hline $\mathrm{t}(3504)$ & 9.3063 & 6.7369 & 8.29895 \\
\hline two-tailed p-value & 0.0000 & 0.0000 & 0.0000 \\
\hline \multicolumn{4}{|c|}{ Companies included in DAX Index } \\
\hline $\begin{array}{c}\text { gEPS } \\
\text { Pearson correlation }\end{array}$ & 0.2591 & 0.0756 & $0.1348 *$ \\
\hline $\mathrm{t}(407)$ & 5.4128 & 1.5301 & 2.7448 \\
\hline two-tailed p-value & 0.000 & 0.1268 & 0.0063 \\
\hline
\end{tabular}

* Results are statistically significant.

Source: author's own study.

Table 17. Spearman's rho between growth ratios

\begin{tabular}{|c|c|c|c|}
\hline & $\mathrm{gS}$ & $\mathrm{gA}$ & $\mathrm{gE}$ \\
\hline \multicolumn{3}{|c|}{ Companies included in WIG Index } \\
\hline $\begin{array}{c}\text { Poland gEPS } \\
\text { coarman rho } \\
\text { correlation }\end{array}$ & 0.4865 & 0.2331 & 0.3026 \\
\hline $\mathrm{t}(3504)$ & 32.9675 & 14.1924 & 18.7987 \\
\hline two-tailed p-value & 0.0000 & 0.0000 & 0.0000 \\
\hline \multicolumn{3}{|c|}{ Companies included in DAX Index } \\
\hline $\begin{array}{c}\text { Germany gEPS } \\
\text { Spearman rho } \\
\text { correlation }\end{array}$ & $0.4703^{*}$ & $0.2147^{*}$ & $0.247^{*}$ \\
\hline t (407) & 10.7533 & 4.43544 & 5.14847 \\
\hline two-tailed p-value & 0.0000 & 0.0000 & 0.0000 \\
\hline
\end{tabular}

* Results are statistically significant.

Source: author's own elaboration. 
The growth of EPS was correlated with the growth of sales, assets and equity in a positive way in case of companies included in WIG Index and the Spearman's rho level indicates a higher relationship compared to Pearson's correlation ratio in this group. In case of growth of assets in a group of companies included in DAX Index this relation was not significant when Pearson correlation with EPS growth was analyzed. Pearson correlation of EPS growth with the growth of sales was higher in the group of DAX listed companies with the sales growth affecting the growth of EPS in a linear way. In case of Spearman's rho the ratios were slightly higher for the companies included in WIG Index.

\section{DISCUSSION OF RESULTS}

The results show that the EPS growth was higher in the group of companies included in WIG Index and this group of companies was characterized by a higher level of standard deviation of growth factors. On the other ha the growth of equity was higher in the group of companies included in DAX Index indicating higher investments in larger companies. The growth of EPS was correlated with the growth of sales, assets and equity in a positive way in a group of companies included in WIG Index and the Spearman's rho level indicated higher relationship comparing to Pearson's correlation in this group of companies. In case of growth of assets in a group of companies included in DAX Index this relation was not significant when Pearson's correlation with EPS growth was analyzed. Pearson correlation with the growth of sales was higher in a group of companies included in DAX Index indicating that the sales growth was related with the growth of EPS in a linear way. In case of Spearman's rho the results were slightly higher for the companies included in WIG Index and it could indicate a non-linear function of growth of companies in this group.

Altman's Z-score Model reflects the financial condition of companies along with early warnings. The growth of EPS was correlated with Altman's Z-Score Model scores in a negative way in both groups of companies. The difference is that this relationship was linear in case of the companies included in DAX Index and non-linear in case of the companies included in WIG Index. In case of growth of sales, the only significant correlation was found in the group of companies included in WIG Index and it was negative. In case of growth of assets, the correlation was positive for both groups of companies but this relationship was non- linear in case of companies included in WIG Index. The growth of equity was correlated with Altman's Z-score Model scores in a positive way only in the group of companies included in DAX Index, but this correlation was not linear.

In case of the companies included in WIG Index only market value of equity/book value of debt (MVE/BVD) influenced the growth of EPS in a negative 
way indicating that the growth of debt was stimulating the growth of EPS the same way as the growth of market value, but the second situation was rather a result of EPS growth. In case of the companies included in DAX Index operational profit/assets (EBIT/TA) influenced the growth of EPS in a negative way indicating that the growth of assets reduced the value of company that could be a result of investing in nonprofitable projects. On the other hand, market value of equity/ book value of debt (MVE/BVD) and sales /assets (S/TA) influenced EPS growth in a positive way indicating that the reduction of debt influenced the growth of EPS in a positive way the same as the growth of sales.

In case of the companies included in WIG Index operational profit/assets (EBIT/TA), market value of equity/ book value of debt (MVE/BVD) and sales /assets (S/TA) influenced the growth of sales in a negative way indicating that the growth of assets and growth of debt were related to the growth of sales. In case of companies included in DAX Index only operational profit/assets (EBIT/TA) influenced the growth of sales in a negative way indicating that the growth of assets stimulated the growth of sales.

In case of the companies included in WIG Index operational profit/assets (EBIT/TA) influenced the growth of assets in a positive way indicating the EBIT growth accompanying the growth of assets. In case of the companies included in DAX Index, value of equity/ book value of debt (MVE/BVD) influenced it in the same direction indicating that the debt reduction was related to the growth of assets in a positive way.

In case of companies included in WIG Index operational profit/assets (EBIT/TA) and sales /assets (S/TA) influenced the growth of equity in a positive way indicating that assets reduction was related to the growth of equity in a positive way and market value of equity/ book value of debt (MVE/BVD) in a negative way indicating that debt reduction was positively related to the growth of equity. In case of the companies included in DAX Index only market value of equity/book value of debt (MVE/BVD) influenced the growth of equity in a positive way indicating that the debt growth was related to the equity growth , which is generally possible when a company is developing in a coherent way with the optimal capital structure management.

It is worth to mention that working capital/ assets (WC/TA) and cumulated retained earnings/ assets (CRE/TA) did not influence the growth of any group of companies indicating that working capital and retained earnings did not influence the growth of companies taken into consideration.

The companies included in WIG Index were found to be more risky and the relationship between variables was rather non-linear in comparison to the companies included in DAX Index.

Altman's Z-score Model can be used to assess the condition of the company. It can be expected that the international applicability of the model to other 
countries is affected by country specific differences. Economic environment, legislation, culture, financial markets, and accounting practices in a specific country may affect the financial behavior of firms and the boundary between bankrupt and non-bankrupt entities. These factors may potentially weaken the classification performance of the model and be a limitation of the presented study (Ooghe and Balcaen, 2007: 33-76).

\section{CONCLUSIONS}

The economic condition of a company can influence its growth making it more or less intense. In the presented research, it was found that there exists a negative correlation between Altman's Z-score Model scores and growth of EPS in both markets but the difference is that in the group of WIG listed companies, this relationship is non-linear, and in the group of DAX listed companies it is linear. It can be stated that the higher level of Altman's Z-scores, the lower the growth of EPS, and therefore, a lower level of value creation. Management of every company should be aware of this trade-off. Based on the findings in the presented research, it can be concluded that low levels of Altman's Z-score Model scores should not be interpreted only in a negative way.

In the group of companies included in WIG Index the growth of debt was stimulating the growth of EPS the same as the growth of market value. WIG listed companies did not use debt at an optimal level allowing them to minimize WACC due to the tax shield. In the group of companies included in DAX Index, the reduction of debt influenced the growth of EPS in a positive way. The companies in this group were probably overleveraged, and any reduction in debt influenced EPS in a positive way. Moreover, the growth of assets influenced the growth of EPS in a negative way indicating that the investment projects of companies included in DAX Index might not be profitable.

Additionally, it was found that working capital and retained earnings did not influence the growth of companies in both groups. Moreover, the group of companies can be divided by the value of P/E ratio to test the sample for the difference between the condition and growth of companies in relation to the growth potential.

\section{REFERENCES}

Ahmed, P., Nanda, S. (2001). Style investing: Incorporating growth characteristics in value stocks. The Journal of Portfolio Management, 27(3), pp. 47-59.

Aktas, N., de Bodt, E., Lobez, F., Statnik, J.C. (2012). The information content of trade credit. Journal of Banking and Finance, vol. 36, pp. 1402-1413. 
Altman, E.I. (1968). Financial Ratios, Discriminant analysis and the prediction of corporate bankruptcy. Journal of Finance, 23, 4, September, pp. 589-609.

Altman, E.I. (1983). Corporate Financial Distress. A Complete Guide to Predicting, Avoiding, and Dealing with Bankruptcy. Wiley Interscience, John Wiley and Sons.

Altman, E.I., Hotchkiss, E. (2006). Corporate Credit Scoring-Insolvency Risk Models. In: Corporate Financial Distress and Bankruptcy. New Jersey: Wiley.

Altman, E.I., Iwanicz-Drozdowska, M., Laitinen, E.K., Suvas, A. (2014). Distressed firm and bankruptcy prediction in an international context: A review and empirical analysis of Altman's Z-score model. Available at SSRN 2536340.

Altman, E.I., Yen, J., Zhang, L. (2010). Corporate financial distress diagnosis model and application in credit rating for listing firms in China. Frontiers of Computer Science in China, 4(2), pp. 220-236.

Bankole, K.O., Ukolobi, I.O. (2020). Value Relevance of Accounting Information and Share Price in Financial Service Industry. Research Journal of Finance and Accounting, 11(8), pp. 22221697.

Bărbuță-Mișu, N., Madaleno, M. (2020). Assessment of bankruptcy risk of large companies: European countries evolution analysis. Journal of Risk and Financial Management, 13(3).

Beaver, W.H. (1966). „Financial Ratios and Predictors of Failure. Empirical Research in accounting" Selected Studies, Supplement: Journal of Accounting Research.

Chava, S., Jarrow, R.A. (2004). Bankruptcy prediction with industry effects. Review of Finance, 8 , pp. 537-569.

Czerwińska, A., Michna, A., Męczyńska, A. (2013). Determinanty rozwoju małych i średnich przedsiębiorstw sektora budowlanego. Zarządzanie $i$ Finanse, 4(2), Fundacja Rozwoju Uniwersytetu Gdańskiego, pp. 79-80.

Danbolt, J., Hirst, I.R., Jones, E. (2011). The growth companies puzzle: Can growth opportunities measures predict firm growth? The European Journal of Finance, 17(1), pp. 1-25.

Delmar, F. (2006). Measuring growth: Methodological considerations and empirical results. Entrepreneurship and the Growth of Firms, 1(1), pp. 62-84.

El Khoury, R., Al Beaïno, R. (2014). Classifying manufacturing firms in Lebanon: An application of Altman's model. Procedia-Social and Behavioral Sciences, 109(1), pp. 11-18.

Fitzpatrick, P.J. (1932). A comparison of ratios of successful industrial enterprises with those of failed firms. Certified Public Accountant, 12.

Franc-Dąbrowska, J., Zbrowska, M. (2008). Prognozowanie finansowe dla spółki X - spółka logistyczna. Zeszyty Naukowe SGGW w Warszawie. Ekonomika i Organizacja Gospodarki Żywnościowej, Warszawa: Wydawnictwo SGGW.

Franzen, L.A., Rodgers, K.J., Simin, T.T. (2007). Measuring distress risk: The effect of RandD intensity. The Journal of Finance, 62, 6, pp. 2931-2967.

Grice, J.S., Ingram, R.W. (2001). Tests of the generalizability of Altman's bankruptcy prediction model. Journal of Business Research, 54, pp. 53-61.

Griffin, J.M., Lemmon, M.L. (2002). Book-to-market equity, distress risk, and stock returns. The Journal of Finance, 57(5), pp. 2317-2336.

Hadasik, D. (1998). Upadłość przedsiębiorstw w Polsce i metody jej prognozowania. Wydawnictwo Akademii Ekonomicznej w Poznaniu.

Holder-Webb, L.M., Wilkins, M.S. (2000). The incremental information content of SAS No. 59. Goingconcern opinions. Journal of Accounting Research, 38(1), pp. 209-219.

Kanapickiene, R., Spicas, R. (2019). Credit risk assessment model for small and micro-enterprises: The case of Lithuania. Risks, 7(2).

Kasiewicz, S. (1996). Systemy wczesnego ostrzegania w bankowym funduszu gwarancyjnym (BGF), Restrukturyzacja w procesie przeksztatceń i rozwoju przedsiębiorstw. Kraków: Wydawnictwa Akademii Ekonomicznej w Krakowie. 
Kumar, P.R., Ravi, V. (2007). Bankruptcy prediction in banks and firms via statistical and intelligent techniques - A review. European Journal of Operational Research, 85.

Kwak, W., Shi, Y., Cheh, J.J., Lee, H. (2005). Multiple criteria linear programming data mining approach: An application for bankruptcy prediction. Data Mining and Knowledge Management. Lecture Notes in Computer Science, 3327, pp. 164-173.

Lyandres, E., Zhdanov, A. (2013). Investment opportunities and bankruptcy prediction. Journal of Financial Markets, 16, pp. 439-476.

Merkevicius, E., Garšva, G., Girdzijauskas, S. (2006). A hybrid SOM-Altman model for bankruptcy prediction. International Conference on Computational Science. Lecture Notes in Computer Science, 3994, pp. 364-371.

Ohlson, J.A., Juettner-Nauroth, B.E. (2005). Expected EPS and EPS growth as determinantsof value. Review of accounting studies, 10(2), pp. 349-365.

Ohlson, J.A. (2017). Valuation and growth. Available at SSRN 2983031.

Ooghe, H., Balcaen, S. (2007). Are failure prediction models widely usable? An empirical study using a Belgian dataset. Multinational Finance Journal, 11(1/2), pp. 33-76.

Piotroski, J.D. (2000). Value investing: The use of historical financial statement information to separate winners from losers. Journal of Accounting Research, 38, Supplement: Studies on accounting information and the economics of the firm, pp. 1-41.

Reisz, A.S., Perlich, C. (2007). A market-based framework for bankruptcy prediction. Journal of Financial Stability, 3, pp. 85-131.

Siekelova, A., Kovalova, E., Ciurlău, C.F. (2019). Prediction financial stability of Romanian production companies through Altman Z-score. Ekonomicko-manazerske spektrum, 13(2), pp. 89-97.

Vochozka, M., Vrbka, J., Suler, P. (2020). Bankruptcy or success? The effective prediction of a company's financial development using LSTM. Sustainability, 12(18).

Waśniewski, T., Skoczylas, W. (1993). Analiza symptomów zagrożenia przedsiębiorstwa. Rachunkowość, 12.

Weinzimmer, L.G., Nystrom, P.C., Freeman, S.J. (1998). Measuring organizational growth: Issues, consequences and guidelines. Journal of management, 24(2), pp. 235-262.

Witkowska, D., Kuźnik, P. (2019). Does fundamental strength of the company influence its investment performance? Dynamic Econometric Models, 19, pp. 85-96.

Xu, M., Zhang, C. (2009). Bankruptcy prediction: The case of Japanese listed companies. Review of Accounting Studies, 14, pp. 534-558.

Zaleska, M. (2002). Identyfikacja ryzyka upadłości przedsiębiorstwa i banku, Warszawa: Difin.

\section{Kondycja przedsiębiorstw i ich wzrost na przykładzie spółek wchodzących w skład indeksów WIG i DAX}

\section{Streszczenie}

Cel artykułu / hipoteza: W prezentowanej pracy omówiono problem kondycji przedsiębiorstw wraz z ich wzrostem reprezentowanym przez zysk na akcję, sprzedaż, majątek oraz kapitał własny. Kondycję przedsiębiorstwa na rynku kapitałowym uznaje się za dobrą w momencie osiągnięcia celu biznesowego, jakim jest wzrost wartości, który następuje wraz ze wzrostem zysku na akcję. Zakładamy, że kondycja firm mierzona punktami Z-score Model Altmana jest związana z ich wzrostem, a wskaźniki zastosowane w tym modelu wpływają na wzrost spółek reprezentowany przez wzrost EPS, wzrost sprzedaży, wzrost aktywów i wzrost kapitałów własnych. Badanie zostało prowadzone 
w dwóch grupach spółek, z których jedna grupa reprezentuje spółki giełdowe tworzące indeks WIG, a druga spółki giełdowe tworzące indeks DAX.

Metodologia: wzrost zysku na akcję jest uważany za miarę tworzenia wartości przedsiębiorstw. Wzrost EPS powinien być powiązany ze wzrostem sprzedaży, aktywów i kapitałów włąsnych zgodnie $z$ teorią wzrostu przedsiębiorstw. Aby ocenić wpływ modelu Z-score Altmana na wzrost EPS, sprzedaży, aktywów i kapitału, zastosowano korelację Pearsona i Spearmana. Ponadto modele logitowe zostały zastosowane do analizy wpływu wskaźników składających się na model Z-score Altmana na wzrost EPS, sprzedaży, aktywów i kapitału.

Wyniki badań: Modele dyskryminacyjne mogą być wykorzystywane do oceny kondycji ekonomicznej przedsiębiorstw, ale interpretacja wyników powinna uwzględniać fakt, że ryzykowne strategie identyfikowane przez modele Z-score Model Altmana jako obarczone dużym ryzykiem bankructwa są związane z wyższym wzrostem zysku na akcję, a co za tym idzie wzrostem wartości.

Słowa kluczowe: wzrost przedsiębiorstwa, modele dyskryminacyjne, model Altmana. 